\title{
SOSIALISASI DAN PELATIHAN PEMBUATAN KASCING SERTA PEMANFAATANNYA UNTUK PENGENDALIAN PENYAKIT TANAMAN DI DESA PAGERWANGI, LEMBANG, BANDUNG BARAT
}

\author{
Noor Istifadah, Ceppy Nasahi, Fitri Widiantini, dan Sri Hartati.
}

Departemen Hama dan Penyakit Tumbuhan, Fakultas Pertanian Universitas Padjadjaran

E-mail: n.istifadah@unpad.ac.id

\begin{abstract}
ABSTRAK. Sebagian besar masyarakat Desa Pagerwangi, Lembang, Bandung Barat adalah petani dan peternak terutama ternak sapi. Salah satu kendala utama yang dihadapi petani dalam budidaya tanamannya adalah adanya penyakit. Penggunaan pestisida yang terus menerus dapat menimbulkan berbagai dampak negatif. Salah satu cara pengendalian yang ramah lingkungan adalah dengan menggunakan bahan organik. Namun demikian banyak petani yang belum tahu mengenai hal tersebut. Tujuan kegiatan pengabdian kepada masyarakat ini adalah untuk menyosialisasi dampak negatif dari pestisida dan perlunya pengendalian secara ramah lingkungan terutama dengan pemanfaatan bahan organik. Program yang telah dilaksanakan adalah penyuluhan tentang pentingnya pengendalian secara ramah lingkungan dan pemanfaatan bahan organik untuk pengendalian penyakit untuk petani di RW 10. Kegiatan ini ditindaklanjuti dengan pemberian benih sayuran dan pengarahan pemanfaatan bahan organik untuk pembuatan pupuk organik cair dan untuk pengendalian penyakit tanaman. Guna mendukung produksi bahan organik, dilakukan juga program yang berupa penyuluhan tentang pemanfaatan kotoran sapi untuk budidaya cacing yang limbahnya yaitu berupa kascing merupakan bahan organik yang sangat baik untuk pupuk dan juga pengendali penyakit tanaman. Penyuluhan ini ditindaklanjuti dengan adanya pelatihan budidaya cacing dan pembuatan kascing yang diikuti peternak, petani, serta wanita tani dari RW 03 dan RW 10. Selain diberikan keterampilan, peserta juga diberikan media dan bibit cacing, serta kotak kayu serta unit percontohan untuk budidaya cacing. Pendampingan dan koordinasi juga dilakukan untuk memfasilitasi pelaksanaan budidaya cacing, produksi kascing serta pemanfaatannya dalam budidaya tanaman ramah lingkungan.
\end{abstract}

Kata kunci: bahan organik; budidaya cacing; kotoran sapi; percontohan; pendampingan

\section{SOCIALIZATION AND TRAINING ON VERMICOMPOSTING AND ITS USE FOR PLANT DISEASE CONTROL IN PAGERWANGI VILLAGE, LEMBANG, WEST BANDUNG}

\begin{abstract}
Most of people in Pagerwangi Lembang, Bandung Barat are farmers. One of problems in crop cultivation is plant diseases. The most common methods used for the disease control is the use of pesticides. The excessive use of pesticides can lead to various negative impacts and hence ecofriendly control methods need to be developed including the use of organic matters for plant disease control. The objective of this program was to socialize the importance of ecofriendly control measures particularly the use of animal manures for plant disease control and production of vermicompost. The activities conducted were social services discussing those issues to farmers in RW 10. This activities was followed by providing vegetable seeds and guiding the preparation and the use of animal manures for liquid organic fertilizer and disease control. For supporting the availabilities of organic matters, other activities that were conducted were training and demonstration on the earthworm cultivation and vermicompost production. The advantageous of vermicompost including its efficacy in controlling plant diseases were also discussed. The activities involved the farmers from RW 03 and RW 10 . The participants were also provided with set of equipment and materials for earthworm cultivation. Facilitation was conducted on the earthworm cultivation, vermicompost production and its utilization for supporting ecofriendly agriculture.
\end{abstract}

Key words: organic matters; earthworm; animal manures; demonstration plot; facilitation

\section{PENDAHULUAN}

Desa Pagerwangi merupakan salah satu desa di wilayah Kecamatan Lembang, Bandung Barat. Sebagian besar masyarakat di desa tersebut mempunyai mata pencaharian sebagai petani dan juga peternak terutama sapi atau kambing. Permasalahan yang dihadapi oleh petani terutama di musim hujan adalah adanya penyakit tanaman baik yang menginfeksi perakaran, pangkal batang ataupun bagian tanaman di atas tanah. Selama ini, petani di Desa Pagerwangi yang merupakan petani sayuran sudah biasa menggunakan pestisida sintetik untuk mengendalikan penyakit tanamannya. Namun demikian, penggunaan pestisida yang terus menerus dan dengan dosis yang berlebihan dapat menimbulkan berbagai dampak negatif. Oleh karena itu, perlu upaya untuk menyosialisasikan cara pengendalian yang ramah lingkungan, diantaranya adalah dengan pemanfaatan bahan organik. Secara umum, bahan organik yang biasa digunakan petani untuk budidaya tanaman adalah kotoran hewan (kohe) sapi, kambing atau kohe ayam. Selain itu, bahan organik yang juga digunakan sebagai pupuk organik adalah kompos dan kascing (bekas cacing).

Pada dasarnya, bahan organik selain dapat dimanfaatkan sebagai pupuk organik, dapat pula dimanfaatkan sebagai bahan untuk pengendalian penyakit tanaman. Aplikasi bahan organik seperti kotoran hewan, kompos atau kascing pada media pertanaman telah dilaporkan dapat menekan penyakit terbawa tanah (Bonanomi, 2007). Selain untuk mengendalikan penyakit tular tanah, bahan organik dalam bentuk air rendamannya juga dapat 
digunakan untuk pengendalian penyakit tular udara (St. Martin, 2012).

Selain sebagai petani, masyarakat Desa Pagerwangi juga mempunyai mata pencaharian sebagai peternak. Selama ini kotoran hewan atau kohe yang ada hanya digunakan untuk pupuk organik saja. Pada musim hujan, kohe sapi banyak menumpuk karena sebelum dapat digunakan untuk pupuk, kohe sapi yang sangat basah perlu dikeringkan dulu. Oleh karena itu, diperlukan inovasi untuk mengatasi permasalahan tersebut. Permasalahan kohe sapi yang menumpuk tersebut dapat disolusikan dengan adanya budidaya cacing tanah. Cacing tanah banyak dibudidayakan di Indonesia adalah jenis Lumbricus rubellus (Palungkun, 1999).

Budidaya cacing tanah dapat menghasilkan cacing yang dapat dimanfaatkan sebagai bahan baku pembuatan pakan ternak dan ikan, serta bahan baku obatobatan dan kosmetik (Palungkun, 1999; Munroe, 2003). Limbah budidaya cacing tanah yang disebut kascing juga sangat bermanfaat bagi pertumbuhan tanaman. Kascing mengandung unsur hara yang diperlukan oleh tanaman seperti N, P, K, Mg, Ca. Kandungan unsur hara tersebut terutama Nitrogen lebih tinggi daripada kompos. Kascing juga mengandung berbagai mikroba pemacu pertumbuhan tanaman yang dapat menghasilkan hormon pertumbuhan. Selain itu, cacing tanah sendiri dapat mengeluarkan hormone pertumbuhan tanaman seperti auksin dan sitokinin. Ekskresi yang dihasilkan oleh cacing tanah juga dapat menstabilisasi asam humat sehingga meningkatkan absorpsi dan ketersediaan hormon-hormon tersebut bagi tanaman (Sarma et al., 2010; Sreenivasan, 2014). Selain itu, kascing juga dapat mengendalikan penyakit tanaman (Ersahin, 2010; Sarma et al., 2010).

Kemampuan kascing untuk mengendalikan penyakit tanaman telah banyak dilaporkan (Ersahin, 2010; Sarma et al., 2010). Aplikasi kascing ke media tanam, dapat menekan penyakit layu Fusarium pada tomat (Istifadah, 2001), penyakit akar gada pada pakchoy (Istifadah dkk., 2018) serta menekan nematoda sista kentang (Istifadah et al., 2019). Selain penyakit tular tanah, air rendaman kascing juga dapat mengendalikan penyakit tular udara. Singh et al. (2003) melaporkan bahwa penyemprotan dengan air rendaman kascing dapat menurunkan intensitas penyakit embun tepung pada tanaman kacang polong di lapangan. Hasil penelitian Zaller (2006) juga menunjukkan bahwa penyemprotan tanaman tomat dengan air rendaman kascing dapat menurunkan intensitas penyakit hawar daun Phythophthora. Istifadah dan Nasahi (2007) melaporkan bahwa air rendaman kascing dapat menekan penyakit karat pada tanaman kedelai. Kemampuan kascing dalam menekan penyakit tanaman dapat melalui beberapa mekanisme antara lain kascing mengandung mikrob yang bersifat antagonistik terhadap patogen. Selain itu kascing juga dapat meningkatkan ketahanan tanaman terhadap penyakit (Sarma et al., 2010).

Mempertimbangkan permasalahan dan potensi yang ada di Desa Pagerwangi, maka dilakukan kegiatan pengabdian masyarakat yang bertujuan untuk menyosialisasikan dan meningkatkan keterampilan peternak dan petani dalam pemanfaatan kohe sapi untuk budidaya cacing dan produksi kascing. Kegiatan juga bertujuan untuk meningkatkan wawasan dan kesadaran petani mengenai pentingnya pengendalian secara ramah lingkungan termasuk pengendalian dengan bahan organik seperti kascing.

\section{METODE}

Kegiatan Pengabdian pada Masyarakat (PPM) ini dilaksanakan di Desa Pagerwangi, Lembang, Kabupaten Bandung Barat dari bulan Mei sampai Oktober 2019. Metode yang digunakan adalah pendidikan masyarakat atau penyuluhan, pelatihan, dan konsultasi atau pendampingan. Tahapan dalam pelaksanaan kegiatan adalah sebagai berikut:

1) Survey dan penjajagan. Survey dilakukan sebanyak dua kali. Pada survey pertama, surat izin untuk melakukan PPM diberikan kepada fihak aparat Desa Pagerwangi. Pada saat survey tersebut, dilakukan diskusi dengan Bapak Kepala Desa dan aparat desa mengenai kondisi masyarakat dan berbagai potensi desa. Survey tersebut juga untuk memperoleh informasi tentang ketua kelompok tani dan tokoh yang dapat memfasilitasi kegiatan yang akan dilakukan. Pada survey kedua, dilakukan diskusi dengan ketua kelompok tani serta ketua kelompok ternak tentang permasalahan dan kemungkinan kegiatan yang dapat dilakukan. Pada diskusi tersebut disepakati juga mengenai tanggal dan tempat penyuluhan serta pelatihan.

Pembekalan dan koordinasi dengan mahasiswa KKNM, karena kegiatan PPM ini diintegrasikan dengan kegiatan Kuliah Kerja Nyata Mahasiswa (KKNM). Oleh karena itu, sebelum pelaksanaan kegiatan dilakukan pertemuan untuk koordinasi dan pembekalan bagi mahasiswa yang akan terlibat dalam kegiatan PPM. Pada pertemuan tersebut, didiskusikan mengenai rencana kegiatan dan peran mahasiswa dalam kegiatan PKM ini. Peran mereka antara lain membantu dalam koordinasi dengan petani serta mempersiapkan dan mengorganisir pelaksanaan kegiatan.

Mengingat mahasiswa KKN yang terlibat dalam kegiatan berasal dari berbagai fakultas, maka agar mereka tahu tentang materi pada program, dilakukan juga pembekalan terkait materi untuk meningkatkan wawasan mereka. Hal ini sangat membantu ketika mereka mengadakan wawancara ke peserta terkait dengan pengedalian hama dan penyakit dan pemanfaatan limbah kotoran hewan ternak mereka.

2) Penyuluhan. Kegiatan penyuluhan dilakukan terhadap kelompok peternak untuk menyosialisasikan mengenai pemanfaatan kotoran hewan untuk budidaya cacing 
yang akan menghasilkan kascing. Penyuluhan juga dilakukan untuk kelompok tani untuk meningkatkan wawasan mereka tentang perlunya pengendalian secara ramah lingkungan dan pemanfaatan bahan organik seperti kascing untuk pengendalian penyakit tanaman.

4) Pelatihan dan pembuatan percontohan. Kegiatan pelatihan dilakukan untuk meningkatkan keterampilan peternak dan petani dalam pemanfaatan kotoran hewan ternaknya untuk budidaya cacing yang nantinya juga akan menghasilkan bahan organik berupa kascing. Guna memberikan contoh bagaimana mengelola budidaya cacing maka setelah pelatihan dibuat juga percontohan serta pemberian alat dan bahan untuk budidaya cacing dan produksi kascing.

5) Pendampingan. Pendampingan dilakukan terhadap pelaksanaan budidaya cacing dan produksi kascing serta budidaya tanaman sayuran secara ramah lingkungan. Pendampingan dilakukan dengan kunjungan secara langsung serta komunikasi melalui telepon dan media sosial.

\section{HASIL DAN PEMBAHASAN}

\section{Penyuluhan Pemanfaatan Kotoran Hewan untuk Budidaya Cacing dan Pembuatan Kascing}

Kegiatan inibertujuan untukmeningkatkan wawasan peternak dan petani dalam memanfaatkan limbah ternak guna budidaya cacing yang nantinya limbah cacingnya yang disebut kascing dapat digunakan untuk pupuk dan pengedali penyakit tanaman. Limbah kotoran sapi yang dihasilkan oleh para peternak merupakan masalah yang dapat mengganggu kesehatan lingkungan dan menjadi salah faktor pencemar dari Sungai Cikapundung. Pengolahan limbah kotoran sapi untuk budidaya cacing dapat dijadikan salah satu alternatif dalam mengurangi limbah kotoran sapi di Desa Pagerwangi. Kegiatan penyuluhan diikuti oleh anggota kelompok peternak Sari Wangi dan ibu-ibu petani dari RW 03, Desa Pagerwangi

Dari hasil wawancara dengan peserta, sebagian besar dari mereka masih belum tahu mengenai pemanfaatan kotoran hewan ternak untuk budidaya cacing. Sebenarnya ketua kelompok ternaknya sudah pernah mengikuti penyuluhan di Desa Suntenjaya, Lembang tentang budidaya cacing tanah. Namun demikian, pada saat itu tidak dilakukan praktek budidayanya. Beberapa peserta lain juga pernah mendengar tentang bisnis cacing tanah, namun belum tahu tentang cara budidayanya. Para peserta juga tidak tahu bahwa sebenarnya hasil sampingan dari budidaya cacing yaitu kascing merupakan pupuk organik yang nilai ekonominya lebih tinggi daripada kompos.

Materi yang diberikan pada penyuluhan meliputi manfaat dan nilai ekonomi dari cacing tanah, berbagai jenis cacing yang dapat dibudidayakan, cara menyiapkan media hidup, pemeliharaannya termasuk jenis pakan, cara menyiapkan/memberikannya serta cara panen cacing dan kascingnya. Penjelasan juga mencakup manfaat dari kascing sebagai pupuk organik dan sebagai bahan untuk mengendalikan penyakit tanaman. Pada acara tersebut disampaikan pula hasil-hasil penelitian yang menunjukkan keefektifan kascing dalam mengendalikan penyakit pada perakaran maupun yang ada pada daun serta bagaimana cara aplikasinya.

Dari penjelasan pada saat penyuluhan hampir semua peserta baru tahu bahwa budidaya cacing tidak hanya menghasilkan cacing, tapi juga mendapatkan hasil sampingan berupa kascing yang juga mempunyai nilai jual yang cukup tinggi karena kandungan unsur haranya lebih baik daripada kompos. Kascing yang sudah dapat dipanen dua minggu sekali menunjukkan bahwa pengkomposan dengan menggunakan cacing tanah sangat efektif dan efisien. Penguraian bahan organik dengan bantuan cacing tanah dapat lebih cepat $3-5$ kali dibandingkan dengan penguraian tanpa bantuan cacing tanah. Dari limbah organik yang tersedia untuk budidaya cacing tanah dapat menghasilkan kascing sebanyak 40-50\% persennya (Palungkun, 1999; Munroe, 2003). Sebagian peserta yang merupakan peternak sekaligus petani tertarik untuk mencoba memproduksi kascing dan menggunakannya untuk budidaya tanamannya.

Pada saat sesi tanya jawab, warga sangat aktif bertanya mengenai materi yang disampaikan. Warga sangat antusias untuk mencoba mempraktekkan budidaya cacing tersebut sehingga mereka sangat berharap untuk dapat mengikuti pelatihan budidaya cacing dan pembuatan kascing yang merupakan tidak lanjut dari kegiatan penyuluhan ini. Mereka juga menanyakan tentang pemasaran dan prospek atau peluang bisnisnya. Terkait dengan hal tersebut, ketua kelompok ternak Sari Wangi di RW 03 bersedia untuk memfasilitasi warga dalam pemasaran cacing atau kascingnya. Guna pemasarannya mereka akan berkoordinasi dengan bandar atau pengepul yang ada di daerah Suntenjaya, Lembang yang memang masih memerlukan banyak pasokan dari daerah sekitarnya.

\section{Penyuluhan Pemanfaatan Bahan Organik untuk Pengendalian Penyakit Tanaman secara Ramah Lingkungan}

Kegiatan penyuluhan ini diikuti oleh petani dan peternak dari RW 10, Desa Pagerwangi. Tujuan utama dari kegiatan ini adalah untuk meningkatkan wawasan petani dalam pemanfaatan bahan organik terutama kascing untuk pengendalian penyakit tanaman yang ramah lingkungan. Selain itu, tujuan penyuluhan ini juga untuk meningkatkan kesadaran petani akan pentingnya pengendalian secara ramah lingkungan serta berbagai teknologi pengendalian penyakit yang dapat diintegrasikan. Hal ini perlu disampaikan karena berdasarkan wawancara yang dilakukan sebelum pemberian materi, masih banyak petani yang melakukan pengendalian dengan menggunakan pestisida karena dianggap paling efektif. Banyak yang masih belum 
tahu berbagai dampak negatif dari penggunaan pestisida secara terus menerus dan cenderung berlebihan. Sebagian besar petani juga belum tahu bahwa cara budidaya yang benar seperti rotasi tanaman, tumpang sari, pengaturan jarak tanam, pemupukan berimbang, penggunaan bahan organik, pemangkasan, penggunaan mulsa perak, pembubunan, dapat menekan penyakit. Cara kultur teknis tersebut dapat diintegrasikan dengan pengendalian lain yang ramah lingkungan seperti pestisida dari tumbuhtumbuhan (pestisida nabati) atau penggunaan atau konservasi musuh alami misalnya dengan penanaman tanaman berbunga di sekitar pertanaman.

Beberapa petani termasuk ketua gabungan kelompok tani (Gapoktan) memang sudah mencoba bebe-rapa teknologi ramah lingkungan seperti penggunaan mikroorganisme lokal (MOL) dan pupuk organik cair. Ada juga petani yang pernah mencoba menggunakan pestisida nabati. Namun demikian, mereka belum tahu prinsip kerjanya sehingga ada beberapa hal yang masih kurang tepat. Mereka juga belum tahu bahan-bahan lain di sekitar mereka yang dapat digunakan untuk pembuatan MOL, POC atau pun pestisida nabati. Oleh karena itu, penjelasan tentang materi tentang pestisida nabati, pembuatan dan manfaat lain dari MOL serta POC sangat membantu memperluas wawasan dan pengetahuan mereka.

Penjelasan tentang pemanfaatan bahan organik untuk pengendalian penyakit juga membuka wawasan sehingga mereka dapat lebih mengoptimalkan penggunaannya. Beberapa petani mempunyai hewan ternak juga sehingga mereka sangat tertarik untuk mengoptimalkan pemanfaatan kotoran hewannya tidak hanya sekedar untuk pupuk organik. Beberapa dari petani yang mempunyai hewan ternak juga sangat tertarik untuk mengikuti pelatihan budidaya cacing tanah untuk menghasilkan kascing yang dapat mereka gunakan untuk mendukung budidaya tanamannya.

Pada kegiatan ini diberikan pula bantuan benih sayuran agar ibu-ibu wanita tani dapat mempraktekkan budidaya tanaman secara ramah lingkungan di pekarangan sekitar rumahnya. Dengan demikian, mereka akan mendapatkan berbagai produk sayuran yang sehat karena bebas dari residu pestisida.

\section{Pelatihan Pemanfaatan Kotoran Hewan untuk Budidaya Cacing dan Produksi Kascing}

Kegiatan ini bertujuan untuk meningkatkan keterampilan peternak yang juga petani dalam budidaya cacing serta produksi kascing. Peserta pelatihan adalah peternak dan petani dari RW 03 dan RW 10. Selain dari tim PPM Unpad, diundang juga narasumber lain yaitu seorang praktisi dalam budidaya cacing atau produsen kascing yang berasal dari Suntenjaya, Lembang, Bandung Barat. Selain memberikan penjelasan tahap-tahap dalam budidaya cacing dan produksi kascing secara detail, praktisi tersebut juga memberikan gambaran dan berbagi pengalaman mengenai prospek dan peluang pasar dari kascing.
Pada kegiatan pelatihan, dilakukan demonstrasi dan praktek beberapa tahapan dalam budidaya cacing. Peserta mempraktekkan cara menyiapkan media untuk budidaya cacing. Guna mempermudah dalam penyediaan media, kascing yang sudah jadi juga dapat digunakan untuk media awal untuk budidaya cacing. Pada saat pelatihan, peserta juga mempraktekkan pencampurkan bibit cacing dengan media tempat hidupnya yang berupa kascing serta pemberian pakan yang berupa kotoran sapi.

Guna memfasilitasi peserta untuk melakukan budidaya cacing di tempat masing-masing, maka pada acara tersebut dilakukan juga pembagian bahan dan peralatan yang diperlukan antara lain kotak-kotak kayu, media untuk hidup cacing serta bibit cacing. Selanjutnya mereka mempraktekkan budidaya cacing di beberapa lokasi di RW 03 dan juga RW 10.

\section{Pendampingan budidaya cacing dan produksi kascing}

Peternak dan petani yang telah diberi bahan dan alat guna budidaya cacing dan pembuatan kascing dimonitor dan didampingi sampai mereka dapat menghasilkan cacing dan kascingnya. Dalam perkembangannya, peserta yang diberi bahan dan alat untuk budidaya cacing ternyata mempunyai ketertarikan yang berbeda terhadap produk yang ingin diperolehnya. Sebagian peternak membudidayakan cacing karena ingin memanen dan menjual cacingnya. Jenis cacing yang mereka kembangkan adalah Lumbricus rubellus karena banyak dibutuhkan untuk bahan baku obat dan kosmetik. Untuk kelompok yang ini, guna meningkatkan produksi cacingnya, selain kotoran sapi mereka juga menggunakan sampah rumah tangga yang telah dihaluskan untuk pakan cacingnya. Untuk kelompok ini, pemeliharaan cacing tidak begitu memperhatikan tempat penyimpanan kotak pemeliharaan dan kelembaban tempatnya. Namun demikian, kemurnian/keseragaman jenis bibit cacing, sangat diperhatikan. Mereka tidak mau cacing yang dihasilkan adalah campuran dari beberapa jenis cacing karena itu akan mempengaruhi harga jualnya.

Sebagian peternak lain dan petani yang mempunyai ternak, mereka lebih tertarik untuk memproduksi kascingnya. Untuk yang bertujuan memproduksi kascing, maka pemeliharaan dan tempat cacingnya sangat diperhatikan. Kotak pemeliharaan harus selalu tertutup agar kualitas kascing yang dihasilkannya bagus. Pakan cacing juga lebih diutamakan kotoran sapi atau kambing agar hasil kascingnya halus dan remah. Untuk yang bertujuan mendapatkan kascingnya, kemurnian dari bibit cacing tidak terlalu dipermasalahkan.

Di antara peserta yang mempraktekkan budidaya cacing, ada peternak yang berhasil mengembangkan kascingnya. Peternak tersebut awalnya hanya diberikan tiga kotak pemeliharaan berukuran $60-80 \mathrm{~cm}$, media serta bibit cacing. Dalam dua minggu, kascing yang dapat dipanen ternyata mencapai $25 \mathrm{~kg}$. Untuk memperbesar kuantitas produksi kascingnya, maka cacing yang 
dihasilkan tidak dijual, namun dikumpulkan untuk digunakan lagi sebagai bibit untuk pembuatan kascing berikutnya. Guna mendukung petani tersebut, maka diberikan lagi bantuan kotak budidaya menjadi 10 kotak. Selain itu, telah dilakukan juga upaya untuk membantu pemasaran kascingnya yaitu dengan memperkenalkan peternak tersebut dengan distributor dan pengepul kascing di daerah Cikidang yang memang memerlukan kascing dalam jumlah yang besar.

Beberapa peternak di bawah koordinasi ketua kelompok ternak Sari Wangi bekerjasama dengan balai pelatihan lebih tertarik untuk mengembangkan cacingnya. Mereka juga memperbesar tempat budidaya serta jumlah bibit cacingnya sampai mencapai $25 \mathrm{~kg}$ bibit. Karena mereka akan menjual cacingnya, maka bibit cacing yang dibudidayakan juga jenisnya harus sama yaitu cacing jenis L. rubellus tanpa adanya campuran dari jenis cacing yang lain. Mereka lebih tertarik untuk membudidayakan cacing jenis tersebut karena paling cepat pertumbuhan dan perkembangannya serta permintaan pasarnya yang relatif tinggi.

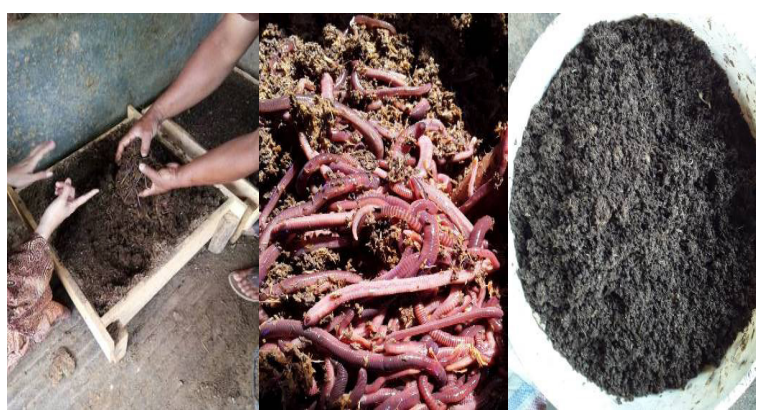

Gambar 1. Percontohan budidaya cacing tanah dan produksi kascing

\section{Pendampingan Budidaya Tanaman secara Ramah Lingkungan}

Pendampingan juga dilakukan terhadap pelaksanaan budidaya tanaman secara ramah lingkungan terutama untuk petani sayuran di RW 10. Beberapa petani sudah membuat POC, namun ada beberapa hal yang masih kurang tepat. Mereka membuat POC dengan cara merendam kohe domba atau sapi dengan air selama 3-5 minggu. Dalam air rendaman tersebut mereka juga memberikan air kelapa, terasi dan gula merah. Sebenarnya yang mereka buat tersebut adalah pupuk organik cair (POC) tapi dicampur dengan bahan yang biasa untuk MOL. Untuk POC dengan kotoran hewan, sebenarnya air kelapa juga tidak terlalu diperlukan. Biasanya air kelapa atau air cucian beras yang pertama digunakan untuk pembuatan MOL yang bahan dasarnya adalah sisa sayuran, sisa buah-buahan, bonggol pisang, rebung dsb. Penggunaan bahan seperti terasi pada pembuatan POC tersebut juga sebenarnya kurang tepat karena fungsinya yang tidak jelas.

Ada juga petani yang dalam air rendaman POC ditambahkan cacahan daun suren atau lengkuas. Mereka menganggap bahan tersebut selain sebagai pupuk juga sebagai pestisida nabati sehingga aplikasinya juga dapat disemprotkan pada daun. Sebenarnya hal ini juga kurang tepat karena bahan untuk pestisida nabati hanya dapat disimpan semalam. Apabila disimpan selama 2-5 minggu maka senyawa toksik yang ada telah terdegradasi sehingga efeknya akan lebih ke arah pupuk.

Pada kegiatan pendampingan, beberapa hal yang kurang tepat tersebut dijelaskan yang seharusnya dan mengapa demikian. Selain itu, dijelaskan juga berbagai bahan lain di lingkungan sekitar petani atau lahan yang dapat digunakan untuk pembuatan pestisida nabati ataupun MOL. Petani juga disarankan untuk menanam bunga-bungaan seperti kenikir atau Tagetes di sekitar lahan karena dapat berfungsi untuk konservasi musuh alami hama tanaman dan juga repelen hama. Beberapa petani yang sudah mulai menerapkan teknologi ramah lingkungan ini diharapkan dapat menjadi motivator bagi petani lain untuk mencoba juga berbagai teknologi ramah lingkungan sehingga akan mengurangi ketergantungan mereka terhadap pestisida sintetik.

\section{Keberlanjutan Program}

Walaupun program telah selesai dilaksanakan, namun konsultasi dan pemantauan tetap dilaksanakan melalui berbagai media misalnya melalui telepon ataupun melalui media sosial. Budidaya cacing tanah dan produksi kascing tetap dipantau perkembangannya. Produksi kascing dapat semakin diperbesar mengingat sudah ada pengepul pupuk kascing yang bersedia untuk menampung kascing dalam jumlah yang cukup besar. Budidaya cacing tanah yang dikoordinir oleh ketua kelompok ternak Sari Wangi juga telah mendapatkan kerjasama dengan balai pelatihan untuk pengembangan lebih besar lagi. Mereka juga telah mendapatkan pengepul cacing yang bersedia membeli cacing tanah yang mereka hasilkan.

Program ini terintegrasi dengan kegiatan Kuliah Kerja Nyata Mahasiswa. Salah satu dari out put program KKNM tersebut adalah adanya proposal Program Kreativitas Mahasiswa tentang budidaya cacing tanah dan produksi kascing. Usulan program ini apabila didanai akan meningkatkan sosialisasi dari produksi salah satu bahan organik yaitu kascing yang merupakan pupuk organik dengan kandungan unsur hara tinggi sekaligus sebagai pengendali penyakit tanaman.

\section{SIMPULAN}

Dari kegiatan yang telah dilaksanakan simpulan yang dapat diambil adalah bahwa: Penyuluhan dan pelatihan mengenai pemanfaatan kotoran hewan untuk budidaya cacing dan pembuatan kascing sangat diminati peternak maupun petani. Keterampilan serta bahan dan alat yang telah diberikan dapat menjadi modal awal untuk memulai usaha tersebut; Program pengabdian masyarakat yang diintegrasikan dengan program $\mathrm{KKN}$ mahasiswa ini juga telah menghasilkan proposal Program Kreativitas Mahasiswa tentang budidaya cacing dan produksi kascing; 
Sosialisasi tentang pengendalian hama penyakit secara ramah lingkungan dan pemanfaatan bahan organik untuk pengendalian penyakit tanaman dapat meningkatkan kesadaran petani untuk mengurangi penggunaan pestisida dan mulai menerapkan berbagai teknologi pengendalian yang ramah lingkungan

\section{UCAPAN TERIMAKASIH}

Kegiatan pengabdian kepada masyarakat ini terlaksana didukung oleh pendanaan PPM yang diberikan melalui DRPMi Universitas Padjadjaran. Terimakasih juga kami sampaikan kepada mahasiswa KKNM Unpad yang terlibat dalam kegiatan PPM ini, aparat Desa terutama pada ketua RW 03 dan RW 10, ketua kelompok ternak Sari Wangi RW 03 (Bapak Inen Rusmana), ketua gabungan kelompok tani (Bapak Tatang), Bapak Syarifudin (dari Desa Suntenjaya) atas dukungan dan bantuannya dalam pelaksanaan kegiatan.

\section{DAFTAR PUSTAKA}

Bonanomi, G., V. Antignani, C. Pane, and F. Scala (2007). Suppression of Soilborne Fungal Diseases with Organic Amendments. Journal Plant Pathology 89 (3): $311-324$

Ersahin, Y. (2010). The Use of Vermicompost Products to Control Plant Disease and Pests. Biology of Earthworms pp. 191-213. DOI: 10.1007/978-3642-14636-7_12. (diakses pada 22 September 2019).

Istifadah, N , M. Nurfitri, dan T. Sunarto (2019). The efficacy of compost, vermicompost and their combination with antagonistic microbes to reduce potato cyst nematode (Globodera rostochiensis). 14 (2): 233-241
Istifadah, N. dan C. Nasahi (2007). Penggunaan Bokasi dan Kascing untuk Menekan Penyakit Karat (Phakopsora pachyrrizi Syd) pada Kedelai. Jurnal Agrikultura, 18:42-47

Istifadah, N.(2001). Kemampuan Kascing dalam Menekan Perkembangan Penyakit Layu Fusarium pada Tanaman Tomat. Agrikultura, 12: 16-21.

Munroe, G. (2003). Manual of On-Farm Vermicomposting and Vermiculture. Organic Agriculture Centre of Canada.

Palungkun, R, (1999). Sukses Beternak Cacing Tanah. Penebar Swadaya, Jakarta.

Sarma B.K., S.K. Pandey, P. Singh, and H.B. Singh (2010). Vermicompost as Modulator of Plant Growth and Disease Suppression. Global Science Book, 58-66.

Singh, U.P., S. Maurya, and D.P. Singh (2003). Antifungal Activity and Induced Resistane in Pea by Aqueous Extract of Vermicomposts and For Control of Powdery Mildew of Pea and Balsam. Journal of Plant Disease and Protection,110:544-553.

St. Martin, C.C.G and R.A.I. Brathwaite (2012). Compost and Compost Tea: Principles and Prospects as Substrates and Soil-Borne Disease Management Strategies in Soil-Less Vegetable Production. Biol. Agric. Hortic. 28 (1): 1-33.

Sreenivasan, E. (2014). Handbook of Vermicomposting Technology. The Western India Plywoods Ltd, Kerala, India

Zaller, J.G. (2006). Foliar Spraying of Vermicompost Extract: Effects on Fruit Quality and Indications of Late Blight Supression of Field Grown Tomatoes. Biological Agriculture and Horticulture 2: 156-180. 